\title{
PERBEDAAN PENINGKATAN KADAR HEMOGLOBIN YANG MENGKONSUMSI TABLET FE DENGAN TABLET FE KOMBINASI VITAMIN C
}

\author{
Ni Made Dwi Suparningsih, Sri Yannarti, Elly Wahyuni \\ Politeknik Kesehatan Kementerian Kesehatan Bengkulu, Jurusan Kebidanan, \\ Jalan Indragiri Nomor 03 Padang Harapan Kota Bengkulu \\ cinta_keluarga16@yahoo.co.id
}

\begin{abstract}
Abstrac: According of Health Research Base (2013), prevalance of anemia in pregnancy $(37,1 \%)$. The provision of iron tablets combination vitamin $\mathrm{C}$ increases of hemoglobin rate. Purpose of this study to known the difference in the enhancement of hemoglobin rate who consumed iron tablets with iron tablets combination vitamin $\mathrm{C}$. This study used quasi experiment design. Samples in this study were 60 . The measurement used hemoglobin digital. The analysis of data used dependent and independent test. Result of this study showed there was difference hemoglobin rate before and after treatments each the group with dependent test showed $(\mathrm{p}=0,000)$. Independent test showed $(\mathrm{p}=0,000)$, there were differences in the enhancement of hemoglobin rate between who consumed iron tablets with iron tablets combination vitamin $\mathrm{C}$. Be expected health workers check the hemoglobin rate when the the fisrt trimester and third trimester, then provide vitamin $\mathrm{C}$ with iron tablets and also provide explanation of the types of foods that contain a lot of vitamin C.
\end{abstract}

Keywords: Hemoglobin, Vitamin C, Iron Tablets

\begin{abstract}
Abstrak : Berdasarkan RISKESDAS (2013), prevalensi anemia ibu hamil di Indonesia $37,10 \%$. Pemberian tablet besi kombinasi vitamin $\mathrm{C}$ meningkatkan hemoglobin lebih tinggi. Tujuan penelitian ini untuk mengetahui perbedaan peningkatan kadar $\mathrm{Hb}$ yang mengkonsumsi tablet $\mathrm{Fe}$ dengan tablet $\mathrm{Fe}$ kombinasi vitamin $\mathrm{C}$. Penelitian ini menggunakan rancangan eksperimen semu dengan desain pretes postet, sampel sebanyak 60 ibu hamil. Pengukuran $\mathrm{Hb}$ digital. Analisis data menggunakan uji t-dependen dan t-independen. Hasil Penelitian menunjukkan ada perbedaan kadar $\mathrm{Hb}$ sebelum dan sesudah perlakuan, uji t-dependen $(\mathrm{p}=0.000)$. Hasil uji t-independen $(\mathrm{p}=0.000)$, berarti ada perbedaan peningkatan kadar hemoglobin yang mengkonsumsi tablet Fe dengan tablet Fe kombinasi vitamin C. Diharapkan petugas kesehatan melakukan pemeriksaan kadar $\mathrm{Hb}$ ibu hamil pada trimester I dan III, pemberian tablet $\mathrm{Fe}$ dengan vitamin $\mathrm{C}$ dan penjelasan tentang makanan yang banyak mengandung vitamin $\mathrm{C}$.
\end{abstract}

Kata Kunci: Hemoglobin, Tablet Fe, Vitamin C

Masalah prioritas bidang kesehatan di indone-sia adalah tingginya angka kematian ibu (AKI). AKI di Provinsi Bengkulu tahun 2012 meningkat yaitu sebesar 136 per 100.000 kelahiran hidup. Penyebab kematian ibu tidak langsung merupakan penyakit yang sudah ada atau timbul saat hamil yang diperberat oleh adaptasi fisiologi terhadap kehamilan, salah satunya adalah kadar hemoglobin yang rendah (Saifuddin, 2008).

Menurut hasil Riset Kesehatan Dasar RISKESDAS (2013), prevalensi anemia ibu hamil di Indonesia sebesar 37,1\%. Berdasarkan data rekapitulasi di Puskesmas Sawah Lebar Tahun 2012, prevalensi anemia sebesar $39,25 \%$.

Menurut Bakta (2006), faktor yang mempengaruhi kadar hemoglobin adalah kecukupan zat besi yang meningkat, penyakit infeksi dan metabolisme yang membantu proses penyerapan zat besi.

Tubuh manusia mengandung sekitar 2 sampai 4 gram besi. Lebih dari $65 \%$ zat besi ditemukan di dalam hemoglobin dalam 
darah atau lebih dari $10 \%$ ditemukan di mioglobin, sekitar $1 \%$ sampai $5 \%$ ditemukan sebagai bagian enzim dan sisa zat besi ditemukan di dalam darah atau ditempat penyimpanan. Jumlah total besi ditemukan dalam orang tidak hanya terkait berat badan tetapi juga pengaruh dari berbagai kondisi psikologi termasuk umur, jenis kelamin kehamilan dan status tingkat pertumbuhan. Besi merupakan mineral mikro yang paling banyak terdapat di dalam tubuh manusia yaitu sebanyak 3-5 gram di dalam tubuh manusia dewasa. Didalam tubuh sebagian besar $\mathrm{Fe}$ terkonjugasi dengan protein dan terdapat dalam bentuk ferro atau ferri. Bentuk aktif zat besi biasanya terdapat sebagai ferro, sedangkan bentuk inaktif adalah sebagai ferri(misalnya dalam bentuk storage). Besi, mempunyai beberapa tingkat oksidasi yang bervariasi dari Fe6+ menjadi Fe2-, tergantung pada suasana kimianya. Hal yang stabil dalam cairan tubuh manusia dan dalam makanan adalah bentuk ferri $(\mathrm{Fe} 3+)$ dan ferro $(\mathrm{Fe} 2+)$.

Pemberian tablet besi dengan penambahan vitamin $\mathrm{C}$ dapat meningkatkan kadar hemoglobin yang tertinggi dibandingkan dengan penambahan suplementasi vitamin lain Suplementasi kombinasi antara zat besi dan vitamin $\mathrm{C}$ akan memberikan dampak nyata berupa kenaikan status zat besi, jika diberikan pada subyek penderita anemia. (Saidin, 1997).

Rendahnya kadar hemoglobin pada trimester I menyebabkan abortus, pada trimester II dan III menyebabkan terjadinya partus prematur, perdarahan antepartum dan gangguan pertumbuhan janin dalam rahim (Mansjoer, 2008). Cakupan ibu hamil yang mendapat tablet Fe di sebesar $88,00 \%$, Sedangkan target nasional cakupan pemberian tablet $\mathrm{Fe}$ adalah sebesar $95 \%$.

Tujuan penelitian ini untuk mengeta-hui perbedaan peningkatan kadar $\mathrm{Hb}$ yang mengkonsumsi tablet $\mathrm{Fe}$ dengan tablet $\mathrm{Fe}$ kombinasi vitamin $\mathrm{C}$.

\section{BAHAN DAN CARA KERJA}

Rancangan penelitian yang digunakan adalah rancangan penelitian eksperimen semu (quasi eksperiment) dengan jenis rancangan Pre test-Post test Design.

Penelitian dilakukan pada bulan Desember tahun 2013 sampai bulan Januari tahun 2014 dengan besar sampel sebanyak 60 yang dibagi menjadi dua kelompok yaitu ekspe-rimen yang diberi tablet Fe kombinasi vitamin $\mathrm{C}$ dan kelompok control yang diberi tablet $\mathrm{Fe}$, sehingga jumlah sampel masingmasing ke-lompok perlakuan sebanyak 30 sampel.

Instrumen yang digunakan dalam penelitian ini adalah alat pemeriksaan laboratorium hemoglobin digital dengan merek dagang quick check, format hasil pemeriksaan kadar hemoglobin sebelum dan sesudah perlakuan, dan format daftar tilik untuk mengetahui keteraturan dalam mengkonsumsi tablet $\mathrm{Fe}$ dan vitamin $\mathrm{C}$.

Analisis data penelitian ini menggunakan komputerisasi dengan uji statistik uji beda yaitu uji $t$ dependen dan uji $t$ independen.

\section{HASIL}

Tabel 1. Rerata Kadar Hemoglobin Ibu Hamil Sebelum dan Sesudah Perlakuan

\begin{tabular}{lcccc}
\hline Kadar Hb & n & rerata & min & max \\
\hline Kelompok Tablet & & & & \\
Fe+Vit C & & & & \\
Sebelum & 28 & 10,5 & 8,7 & 12,1 \\
Sesudah & 28 & 11,5 & 10,3 & 13,5 \\
Kelompok Tablet & & & & \\
Fe & & & & \\
Sebelum & 29 & 10,8 & 9,0 & 12,4 \\
Sesudah & 29 & 11,9 & 10,1 & 13,5 \\
\hline
\end{tabular}

Berdasarkan hasil pada Tabel 1 menunjukkan bahwa kadar $\mathrm{Hb}$ pemberian tablet Fe terendah adalah sebelum mengkonsumsi tablet Fe sebesar 9,0 gr/dl, pemberian tablet $\mathrm{Fe}$ kombinasi vitamin $\mathrm{C}$ kadar $\mathrm{Hb}$ terendah adalah sebelum mengkonsumsi tablet Fe sebesar 8,7 gr/dl, sedangkan peningkatan kadar $\mathrm{Hb}$ pada pemberian tablet $\mathrm{Fe}$ dengan tablet $\mathrm{Fe}$ kombinasi vitamin $\mathrm{C}$ menunjukkan peningkatan kadar $\mathrm{Hb}$ terendah adalah ibu hamil yang mengkonsumsi tablet Fe sebesar 0,5 gr/dl.

Berdasarkan hasil analisis pada Tabel 2 didapat ada perbedaan kadar hemoglobin 
ibu hamil sebelum dan sesudah mengkonsumsi tablet $\mathrm{Fe}$ menunjukkan nilai $\mathrm{p}=0.000$ (IK95\% : 0,99-1,20) artinya ada perbedaan kadar hemoglobin ibu hamil sebelum dan sesudah mengkonsumsi tablet Fe. Dan perbedaan kadar hemoglobin ibu hamil sebelum dan sesudah mengkonsumsi tablet $\mathrm{Fe}$ kombinasi vitamin $\mathrm{C}$ menunjukkan nilai $\mathrm{p}=0.000$ (IK 95\% :1,31-1,53) artinya ada perbedaan kadar hemoglobin ibu hamil sebelum dan sesudah mengkonsumsi tablet Fe kombinasi vitamin C.

Tabel 2. Perbedaan Kadar Hemoglobin Ibu Hamil Sebelum Dan Sesudah Mengkonsumsi Tablet Fe Dan Tablet Fe Kombinasi Vitamin C

\begin{tabular}{ccccc}
\hline Kadar Hb & n & $\begin{array}{c}\text { Rerata } \\
\text { Perbedaan Hb }\end{array}$ & p & IK (95\%) \\
\hline $\begin{array}{c}\mathrm{Fe}+ \\
\text { Vitamin C } \\
\mathrm{Fe}\end{array}$ & 28 & 1,4 & 0,000 & $1,31-1,53$ \\
\hline
\end{tabular}

Tabel 3 Perbedaan Peningkatan Kadar Hemoglobin Yang Mengkonsumsi Tablet Fe Dengan Tablet Fe Kombinasi Vitamin C

\begin{tabular}{cccc}
\hline Kadar Hb & $\Delta$ & $\mathbf{p}$ & IK (95\%) \\
\hline $\begin{array}{c}\text { Fe } \\
\text { Fe + Vitamin C }\end{array}$ & 0,3 & 0.000 & $0,16-0,46$ \\
\hline
\end{tabular}

Hasil analisis pada Tabel 3 bahwa perbedaan rata-rata peningkatan kadar hemoglobin ibu hamil yang mengkonsumsi tablet $\mathrm{Fe}$ dengan tablet $\mathrm{Fe}$ kombinasi vitamin $\mathrm{C}$ menunjukkan nilai $p=0.000$ artinya ada perbedaan peningkatan kadar hemglobin yang mengkonsumsi tablet $\mathrm{Fe}$ dengan tablet $\mathrm{Fe}$ kombinasi vitamin $\mathrm{C}$.

\section{PEMBAHASAN}

\section{Perbedaan Kadar Hemoglobin Yang Meng- konsumsi Tablet Fe.}

Berdasarkan analisis univariat bahwa rata-rata kadar hemoglobin ibu hamil sebelum mengkonsumsi tablet $\mathrm{Fe}$ adalah $<11$ $\mathrm{gr} / \mathrm{dl}$. Hal ini sesuai dengan pendapat Tarwonto (2007) bahwa kadar hemoglobin < 11 gr/dl menunjukkan bahwa ibu hamil mengalami anemia.
Berdasarkan RISKESDAS (2013), bahwa prevalensi anemia di Indonesia sebesar $37,10 \%$. Hasil penelitian ini menunjukkan bahwa prevalensi anemia cukup tinggi. Sesuai pendapat Cunningham (2005) menjelaskan bahwa tingginya angka kejadian anemia pada ibu hamil dikarenakan dalam kehamilan terjadi peningkatan kebutuhan zat besi akibat peningkatan volume darah. Sedangkan menurut laporan USAID's, A2Z, Micronutrient and Child Blindness Project, ACCESS Pro-gram, and Food and Nutrition Technical Assistance (2006) menunjukkan bahwa sekitar 50\% dari seluruh jenis anemia akibat dari defisiensi zat besi. Studi di Malawi ditemukan dari 150 ibu hamil terdapat 32\% mengalami defisiensi zat besi. Demikian pula dengan studi di Tanzania memperlihatkan bahwa anemia ibu hamil berhubungan dengan defisiensi zat besi.

Hasil penelitian menunjukkan bahwa rata-rata peningkatan kadar hemoglobin setelah pemberian tablet $\mathrm{Fe}$ adalah sebesar $1,1 \mathrm{gr} / \mathrm{dl}$. Hal tersebut sesuai dengan teori saifuddin (2007), bahwa pemberian preparat $60 \mathrm{mg} /$ hari elemental besi dan 0,25 mg asam folat dapat menaikkan kadar hemoglobin sebanyak $1 \mathrm{gr} \%$ per bulan. Sesuai pula dengan pendapat Arisman (2004), bahwa pemberian zat besi sebanyak $60 \mathrm{mg}$ per hari akan meningkatkan kadar hemoglobin ratarata sebesar 0,2 gr\% selama 7-10 hari pemberian. Sejalan dengan program pemerintah untuk mengatasi masalah anemia kekurangan zat besi pada ibu hamil, maka dilakukan pemberian tablet zat besi pada ibu hamil dengan mendistribusikan tablet tambah darah, dimana 1 tablet berisi $200 \mathrm{mg}$ fero sulfat (60 mg elemen besi) dan $0,25 \mathrm{mg}$ asam folat, yang diberikan minimial sebanyak 90 tablet selama kehamilan.

Berdasarkan hasil analisis bivariat menunjukkan ada perbedaan peningkatan kadar hemoglobin sebelum dan setelah pemberian tablet Fe dengan hasil uji statistik $(\mathrm{p}=0,000)$. Hal ini sesuai dengan teori Sadikin (2008), bahwa zat besi merupakan komponen utama yang memiliki peranan penting dalam pembentukan darah (hemopoiesis), yaitu 
mensintesis hemoglobin sehingga mempengaruhi kadar hemoglobin dalam darah.

Peningkatan kadar hemoglobin sesudah pemberian tablet $\mathrm{Fe}$ berbeda-beda, hal tersebut sesuai dengan pendapat Arisman (2004), bahwa kadar hemoglobin dipengaruhi oleh beberapa faktor, salah satunya adalah rendahnya tingkat penyerapan zat gizi besi di dalam tubuh terutama sumber zat gizi besi nabati (nonheme) yang hanya diserap $1-2 \%$, sedangkan tingkat penyerapan zat gizi besi makanan asal hewani (heme) dapat mencapai 10-20\%. Sejalan dengan pendapat Almatsier, S (2004), bahwa kebiasaan makan dapat mempengaruhi asupan zat gizi besi yang diperlukan untuk pembentukan hemoglobin.

Berdasarkan tabel 3 menunjukkan bahwa peningkatan terendah terjadi pada pemberian tablet yaitu sebesar $0,5 \mathrm{gr} / \mathrm{dl}$. Hal ini sesuai dengan pendapat Jordan, S (2003), bahwa zat besi merupakan unsur penting dalam pem-bentukan hemoglobin dimana absorbsi zat besi tegantung pada kepatuhan pasien dalam mengkonsumsi suplemen zat besi dan interaksi antara obat atau suplemen lain dengan zat besi yang dapat mengurangi absorbsi zat besi. Sejalan pula dengan pendapat Waryana (2010) bahwa ada beberapa jenis makanan dan minuman yang jika dikonsumsi secara bersamaan dengan za besi dapat menghambat absorbsi zat besi dalam pembentukan hemoglobin seperti cokelat, teh, kopi dan susu, dimana jenis makanan dan minuman tersebut dapat mengikat zat besi sehingga menghambat penyerapannya yang menyebabkan rendahnya kadar hemoglobin.

Hasil penelitian Chaerunnisa (2008) me-nunjukkan bahwa konsumsi tablet besi secara teratur memiliki konstribusi terbesar terhadap kadar hemoglobin ibu hamil dimana konsumsi tablet $\mathrm{Fe}$ secara teratur merupakan faktor risiko terbesar dalam meningkatkan kadar hemoglobin terhadap kejadian anemia pada ibu hamil. Hasil penelitian ini sejalan dengan penelitian yang dilakukan oleh Fanny, L (2011) bahwa pemberian tablet besi selama satu bulan mampu meningkatkan rata-rata kadar hemoglobin sebesar 1,23 g\%. Didukung pula oleh penelitian yang dilakukan Kusumawardani, D (2012) dimana pemberian tablet Fe selama satu bulan pada ibu hamil trimester II mampu meningkatkan rata-rata kadar hemoglobin sebesar $1,20 \mathrm{gr} / \mathrm{dl}$.

Perbedaan Kadar Hemoglobin Yang Mengkonsumsi Tablet Fe Kombinasi Vitamin C

Berdasarkan analisis univariat bahwa ratarata kadar hemoglobin ibu hamil sebe-lum mengkonsumsi tablet $\mathrm{Fe}$ kombinasi vitamin $\mathrm{C}$ adalah $<11 \mathrm{gr} / \mathrm{dl}$, sedangkan ratarata kadar hemoglobin ibu hamil setelah mengkonsumsi tablet Fe kombinasi vitamin $\mathrm{C}$ adalah $>11 \mathrm{gr} / \mathrm{dl}$. Hal ini sesuai dengan pendapat Arisman (2004) bahwa peningkatan kadar hemoglobin dalam darah dipengaruhi zat besi dan vitamin $\mathrm{C}$, dimana vitamin $\mathrm{C}$ tersebut berperan dalam membantu penyerapan zat besi dalam makanan. Sejalan pula dengan pendapat Yuniastuti (2008), bahwa vitamin C berperan dalam absorbsi dan metabolisme besi, dimana vitamin $\mathrm{C}$ mereduksi besi feri menjadi fero dalam usus halus sehingga zat besi mudah diabsorbsi. Hasil penelitian ini juga didukung oleh pendapat Gibney (2009) bahwa vitamin $\mathrm{C}$ membantu penyerapan zat besi nonheme serta meningkatkan penyerapan zat besi heme.

Berdasarkan hasil analisis bivariat ada perbedaan kadar hemoglobin sebelum dan setelah pemberian tablet Fe dengan vitamin $\mathrm{C}$ dengan hasil uji statistik ( $\mathrm{p}=0,000$ ). Hasil penelitian ini sesuai dengan teori Saifuddin (2007), bahwa pemberian tablet Fe $60 \mathrm{mg}$ elemen besi dan $025 \mathrm{mg}$ asam folat dapat me-ningkatkan kadar hemoglobin $1 \mathrm{gr} / \mathrm{dl}$ dalam satu bulan, dan sejalan dengan pendapat Almatsier, S (2004) bahwa peningkatan kadar hemoglobin ibu hamil tidak hanya dipengaruhi oleh suplemen besi tetapi dipengaruhi oleh sayuran hijau dan buahbuahan sebagai sumber vitamin $\mathrm{C}$ yang membantu penyerapan zat besi dalam tubuh untuk pembentukan hemoglobin.

Berdasarkan tabel 3 menunjukkkan bahwa peningkatan kadar hemoglobin tertinggi terjadi pada pemberian tablet $\mathrm{Fe}$ dengan vitamin $C$ yaitu sebesar $1,9 \mathrm{gr} / \mathrm{dl}$. 
Hal tersebut sesuai dengan teori Waryana (2010) bahwa vitamin C membantu mengurangi pengaruh negatif dari zat-zat makanan yang mampu menghambat penyerapan zat besi. Selain itu menurut teori Bakta (2006) menjelaskan bahwa bahan pemicu seperti meat factor dan vitamin $\mathrm{C}$ dapat meningkatkan penyerapan zat besi lebih tinggi sehingga mempengaruhi pembentukan hemoglobin dalam darah lebih tinggi dibandingkan tanpa adanya bahan pemicu.

Penelitian ini sejalan juga dengan penelitian Angganis (2009), bahwa pemberian tablet $\mathrm{Fe}$ dengan penambahan vitamin $\mathrm{C}$ pada ibu nifas post seksio sesarea secara signifikan mampu meningkatkan kadar hemoglobin lebih tinggi. Hasil penelitian ini didukung pula oleh Nadimin, dkk (2011) yang menunjukkan bahwa pemberian sumpelen besi dengan vitamin $\mathrm{C}$ dan vitamin $\mathrm{A}$ efektif meningkatkan kadar hemoglobin. Penelitian Haryanta (2005) juga membuktikan bahwa konsumsi makanan sumber nonheme dengan suplementasi vitamin $\mathrm{C}$ dapat meningkatkan kadar hemoglobin secara bermakna.

\section{Perbedaan Peningkatan Kadar Hemoglobin Setelah mengkonsumsi Tablet Fe Dengan Ta- blet Fe Kombinasi Vitamin C.}

Berdasarkan hasil analisis bivariat menunjukkan bahwa perbedaan rata-rata peningkatan kadar hemoglobin ibu hamil yang mengkonsumsi tablet $\mathrm{Fe}$ dengan tablet $\mathrm{Fe}$ kombinasi vitamin $\mathrm{C}$ adalah sebesar 0,3 $\mathrm{gr} / \mathrm{dl}$. Hal ini sesuai dengan pendapat Kristiana dan herti (2008) bahwa zat besi (Fe) dan vitamin $\mathrm{C}$ merupakan faktor yang berhubungan dengan pembentukan sel darah merah dan hemoglobin dalam darah.

Tabel 3 menunjukkan bahwa ada perbedaan peningkatan kadar hemoglobin ibu hamil yang mengkonsumsi tablet $\mathrm{Fe}$ dengan tablet $\mathrm{Fe}$ kombinasi vitamin $\mathrm{C}$ dengan hasil uji statistik t-independen $(\mathrm{p}=0,000)$. Hal ini sesuai dengan pendapat Siregar (2000) bahwa Vitamin $\mathrm{C}$ berperan dalam memindahkan besi dari transferin di dalam plasma ke feritin hati atau vitamin $\mathrm{C}$ berperan dalam mobilisasi simpanan zat besi (Fe), selain itu vitamin $\mathrm{C}$ mempunyai peran dalam pemben- tukan hemoglobin dalam darah, vitamin $\mathrm{C}$ membantu penyerapan zat besi se-hingga dapat digunakan pada proses pembentukan sel darah merah kembali.

Hasil penelitian ini sejalan dengan penelitian yang dilakukan oleh Purti (2010) pada sampel mahasiswa kebidanan yang menunjukkan bahwa ada perbedaan kenaikan kadar hemoglobin antara pemberian tablet Fe dan tablet Fe dan vitamin C. Didukung pula oleh penelitian Alviani, N (2010) yang menunjukkan hasil bahwa terdapat perbedaan pemberian tablet $\mathrm{Fe}$ dan tablet $\mathrm{Fe}$ dengan penambahan vitamin C (50 mg) pada ibu hamil trimester III. Penelitian serupa juga dilakukan oleh Parwati (2009), pada sampel anak usia sekolah dasar menunjukkan hasil bahwa ada perbedaan kadar hemoglobin antara pemberian suplementasi tablet ferro sulfat $200 \mathrm{mg}$ dan tablet ferro sulfat $200 \mathrm{mg}$ dengan vitamin C 50 .

\section{KESIMPULAN}

Berdasarkan hasil penelitian dapat disimpulkan bahwa: rata-rata kadar hemoglobin ibu hamil sebelum mengkonsumsi tablet Fe me-miliki kadar hemoglobin < $11 \mathrm{gr} / \mathrm{dl}$; rata-rata kadar hemoglobin ibu hamil sebelum mengkonsumsi tablet $\mathrm{Fe}$ kombinasi vitamin $\mathrm{C}$ me-miliki kadar hemoglobin $<11$ gr/dl; rata-rata peningkatan kadar hemoglobin ibu hamil yang mengkonsumsi tablet $\mathrm{Fe}$ kombinasi vitamin $\mathrm{C}$ lebih tinggi dibandingkan ibu hamil yang mengkonsumsi tablet Fe; ada perbedaan kadar hemoglobin ibu hamil sebelum dan sesudah mengkonsumsi tablet Fe dan tablet Fe kombinasi vitamin C; ada perbedaan peningkatan kadar hemoglobin ibu hamil yang mengkonsumsi tablet $\mathrm{Fe}$ dengan tablet Fe kombinasi vitamin $\mathrm{C}$.

Berdasarkan hasil penelitian ini diharapkan pemberian tablet $\mathrm{Fe}$ untuk meningkatkan kadar hemoglobin disertai dengan pemberian vitamin C. Selain itu ibu hamil diberikan pula penyuluhan atau konseling tentang tablet Fe termasuk fungsi tablet $\mathrm{Fe}$, cara mengkonsumsi, cara penyimpanan, cara mengatasi efek samping, jenis makanan dan minuman yang dapat membantu dan menghambat penyerapan zat besi serta jenis 
makanan dan minuman yang banyak mengandung vitamin $\mathrm{C}$ untuk membantu

\section{DAFTAR RUJUKAN}

Almatsier, S. 2004. Prinsip Dasar Ilmu Gizi. Jakarta: PT. Gramedia Pustaka Utama.

Angganis, Y, D. 2009. Pengaruh Penambahan Vitamin C Pada Suplementasi Besi Folat Dalam Meningkatkan Kadar hemoglobin Pada Pasien Pasca Seksio Sesares Di RSU PKU Muhammadiyah Klaten. Klaten: Jurnal Kedoktran Indonesia Volume I.

Arisman, 2004. Gizi Dalam Daur Kehidupan. Jakarta: EGC.

Bakta. 2006. Hematologi Klinik Ringkas. Jakarta:EGC.

Chairunnisa. 2008. Analisis Faktor Risiko Kejadian Anemia Pada Ibu Hamil Di Rumah Sakit Ibu Dan Anak Siti Fatimah Makasar (Tesis). Makasar: Universitas Hasanuddin

Cunningham, F. G. 2007. Obstetri Williams. Jakarta: EGC.

Gibney, dkk. 2009. Gizi Kesehatan Masyarakat. Jakarta : EGC

Haryanta. 2005. Pengaruh Konsumsi Makanan Sumber Hem Dan Nonhem Dengan Suplementasi Vitamin C Terhadap Ladar Hemoglobin Pada Anak Sekolah Dasar Yang Mengalami Anemia Defisiensi Zat Besi (Tesis). Makasar: Universitas Hasanuddin.

Jordan, S. 2003. Farmakologi Kebidanan. Jakarta: EGC

Kristiana, L dan Herti M. 2008. Khasiat dan Manfaat Rosela. Jakarta: PT. AgroMedia Pustaka.

Kusumawardani, D. 2012. Pengaruh Pemberian Tablet Fe Terhadap Peningkatan Kadar Hemoglobin Ibu Hamil Trimester III Di dan meningkatkan penyerapan zat besi.

Wilayah Puskesmas Klaten Selatan. Surakarta: Jurnal Poltekkes Kemenkes Surakarta.

Mansjoer, A. 2000. Kapita Selekta Kedokteran. Jakarta: Media Aesculapius

Nadimin, dkk. 2011. Pengaruh Pemberian Suplemen Besi Dan Multivitamin Terhadap Peningkatan Kadar Hemoglobin Mahasiswa Puteri (KTI). Makasar: Poltekkes Makasar.

Parwati, M. 2009. Peran tablet Fe, Asam Folat Dan Vitamin $C$ Terhadap Peningkatan Kadar Hemoglobin Anak Usia Sekolah Dasar Di Desa Gelgel Kecamatan Klungkung Kabupaten Klungkung. Surabaya: UNAIR.

Riset Kesehatan Dasar (RIKESDAS). 2007. Jakarta: Badan Penelitian dan Pengembangan Kesehatan Departemen Kesehatan Republik Indonesia.

Sadikin, M. 2008. Biokimia Darah. Jakarta: EGC.

Saifuddin, A.B. 2008. Pelayanan Kesehatan Maternal Dan Neonatal. Jakarta: Yayasan Bina Pustaka Sarwono Prawirohardjo.

SDKI. 2012. Survei Demografi Kesehatan Indonesia. Jakarta: SDKI.

Siregar, A. M. 2000. Penanggulangan Anemia Gizi Besi Melalui Program Usaha Perbaikan Gizi Keluarga. Medan: FKM USU.

Tarwoto dan Wasnidar. 2007. Buku Saku Anemia Pada Ibu Hamil Dan Konsep Penatalaksanaan. Jakarta: Trans Info Media.

Waryana.2010. Gizi Reproduksi. Yogyakarta: Pustaka Rihama.

Yuniastuti, A. 2008. Gizi dan Kesehatan. Yogyakarta:Graha Ilmu 
